\title{
Feeding by a larval fish community: impact on zooplankton
}

\author{
Pierre Pepin*, Randy Penney \\ Fisheries and Oceans, PO Box 5667, St. John's, Newfoundland A1C 5X1, Canada
}

\begin{abstract}
We studied patterns in the diurnal fluctuations in gut fullness in 11 species of larval fish in Conception Bay, Newfoundland, Canada. From these data and empirical information on prey selection, we estimated the daily consumption rate of microzooplankton by the entire larval fish community for the period May to September in 1985 and 1986. In general, $<0.1 \%$ of the available prey were consumed by larval fish per day, which is considerably less than the P/B ratio typical for temperate copepods found in this region. We conclude that larval fish are unlikely to exert significant grazing pressure on their prey and that density-dependent growth is unlikely to occur during this phase of the life cycle in fish species that use coastal Newfoundland waters as spawning or nursery areas.
\end{abstract}

KEY WORDS: Fish larvae $\cdot$ Feeding $\cdot$ Ingestion $\cdot$ Microzooplankton $\cdot$ Density-dependence Resale or republication not permitted without written consent of the publisher

\section{INTRODUCTION}

For food competition to influence early life survivorship, larval fish must exert a substantial impact on their prey. Cushing (1983) and Jones (1983) argued that this is only possible during later stages of development (i.e. juvenile and beyond). However, these and other studies viewed density-dependent processes from the perspective of single species. Does competition and food limitation become more likely if we consider consumption of prey by the entire ichthyoplankton community?

Eggs and larvae of a single species of fish are generally scarce $\left(<1 \mathrm{~m}^{-3}\right)$ relative to other zooplankton (Smith \& Lasker 1978), and the total biomass of a cohort decreases from spawning until larvae reach approx. $10 \mathrm{~mm}$ in length (Houde 1997). Throughout much of the larval stage, most species feed on similar prey (nauplii and early copepodite stages of calanoid copepods) (Arthur 1976, Last 1978a,b, Economou 1991, Pepin \& Penney 1997). Because the majority of fish species in the north Atlantic spawn during the spring and summer (Sherman et al. 1984), the common feeding patterns and high levels of larval production of

*E-mail: pepin@athena.nwafc.nf.ca many species of fish may increase the potential for interspecific competition among larvae.

This study investigated the feeding patterns of larval fish in Conception Bay, a physically dynamic coastal ecosystem which serves as a spawning site (Laprise \& Pepin 1995) and potential nursery (Anderson \& Dalley 1997) for several species of fish. We describe the diurnal periodicity in stomach contents, estimate consumption rates, and assess the impact of the entire ichthyoplankton community on the zooplankton prey on which larval fish feed. We apply our estimates of consumption over the primary ichthyoplankton production season, May to September. Data from our previous study (Pepin \& Penney 1997) are used to take into account species- and sizedependent patterns of prey selection.

\section{MATERIALS AND METHODS}

Sample collection and processing. Plankton was sampled fortnightly from late May until late September in 1985 and 1986 at 3 locations on the eastern side of Conception Bay $\left(47^{\circ} 37^{\prime}\right.$ N, $\left.52^{\circ} 55^{\prime} \mathrm{W}\right)$ (see Pepin \& Penney 1997 for details). Ichthyoplankton samples were obtained using a $0.75 \mathrm{~m}$ ring net fitted with $165 \mu \mathrm{m}$ 
Nitex and a General Oceanics flow meter, and towed from a $7.5 \mathrm{~m}$ boat at a depth of $8 \mathrm{~m}$ and a speed of 0.3 to $0.5 \mathrm{~m} \mathrm{~s}^{-1}$ for $10 \mathrm{~min}$. This provided a representative sample of the population, as all the stages of species of larval fish are found predominantly in the upper water column and show little evidence of diurnal vertical migration (Pepin unpubl. data). Zooplankton samples were obtained using a similar ring net fitted with $64 \mu \mathrm{m}$ Nitex which was towed over the same path immediately following ichthyoplankton sampling. Samples were preserved in $4 \%$ buffered formaldehyde. Some additional ichthyoplankton and microzooplankton samples were collected using $23 \mathrm{~m}$ vessels towing $0.6 \mathrm{~m}$ bongo nets fitted with 165 and $64 \mu \mathrm{m}$ Nitex and General Oceanics flow meters. Sampling times on both vessels were selected to provide as thorough a coverage of the diurnal feeding cycle as possible. Logistic constraints prevented continuous sampling over a complete cycle on any one occasion. We have therefore combined all samples from different sampling dates to estimate the diurnal feeding pattern.

All fish larvae were sorted from the samples, identified to the lowest taxonomic level possible, and measured for standard length to the nearest millimeter using an ocular micrometer. A subsample of the 11 dominant species of larval fish (Table 1) was taken for stomach analysis. Specimens were selected to ensure that observations of feeding from each species spanned the entire period of their seasonal occurence. For each specimen, the digestive tract was removed and teased apart using fine dissecting needles. Presence or absence of a yolk sac and the state of digestion were noted. The contents were identified to the lowest taxonomic and life stage possible. If the item was unidentifiable, or if a species had continuous growth, its width was measured to the nearest $10 \mu \mathrm{m}$. Otherwise, the size was estimated from the means of the microzooplankton samples described below, to avoid the distortion characteristic of partially digested items.

Zooplankton samples were processed by first removing all the large organisms not contributing to the diet of larval fish (fish, medusae, pteropods and amphipods). Each sample was poured into a $64 \mu \mathrm{m}$ mesh sieve, rinsed with tap water, and suspended in a calibrated beaker filled to the 11 mark. A $1 \mathrm{ml}$ sample was transferred with a Hensen-Stempel pipette and placed in a $100 \mathrm{ml}$ calibrated beaker. A second $10 \mathrm{ml}$ subsample was taken from this volume. In combination, the $1 / 10000$ and $1 / 1000$ subsamples usually contained sufficient organisms for accurate estimation of total abun-
Table 1. Larval fish-sample characteristics

$\begin{array}{lccc} & \begin{array}{c}\text { No. of } \\ \text { specimens }\end{array} & \begin{array}{c}\text { Length } \\ \text { range }(\mathrm{mm})\end{array} & \begin{array}{c}\text { Period } \\ \text { (day of year) }\end{array} \\ \text { Cynoglossus } & 131 & 6-14 & 232-244 \\ \text { platessoides } & 173 & 3-14 & 213-296 \\ & 160 & 4-14 & 239-276 \\ \text { S } & 168 & 3-14 & 206-239 \\ \text { merugineus } & 129 & 3-14 & 173-244 \\ \text { atus } & 194 & 5-14 & 273-276 \\ \text { adspersus } & 202 & 2-14 & 213-276 \\ \text { rcata } & 91 & 2-7 & 198-244 \\ & 183 & 6-14 & 172-181 \\ & 151 & 2-9 & 273-276 \\ & & 6-14 & 198-251 \\ \end{array}$

dance. At least 500 organisms were counted. Animals were identified to the lowest taxonomic level possible, although it was generally difficult to identify to species level some naupliar stages of copepods (with the exception of Temora longicornis). For animals with definite stages (e.g. copepods), widths of 5 individuals of each species and life stage were measured to the nearest $5 \mu \mathrm{m}$. For animals with continuous growth, or those that could not be identified to species, the width of each individual was measured to the nearest $100 \mu \mathrm{m}$, or to $50 \mu \mathrm{m}$ for copepod nauplii. Ten percent of the samples were re-analyzed for quality control.

Total weight of prey ingested was the summed weight of all prey in the stomachs of each larva. Prey widths were converted to dry weight using Pearre's (1980) empirical relationship for copepods and unpublished data for other species (Pepin unpubl. data).

Analysis. To correct for differences in body size among individual larvae, the total weight of prey in the gut of each larva was expressed as gut fullness (GFI):

$$
G F I=\frac{\sum_{i} N_{p(i)} W_{p(i)}}{W_{L}}
$$

where $N_{p(i)}$ is the number of prey of category $i, W_{p(i)}$ is their dry weight, and $W_{L}$ is the dry weight of the larva reported by Pepin (1995). GFI is a useful basis for comparison among larval fish as long as it is isometric (i.e. $\left.\propto W^{1}\right)$, because any allometry in GFI would prevent an assessment of diurnal periodicity using larvae of different body size. To determine if this was an accurate assumption, an analysis of covariance was used to assess whether there was any significant difference in the allometric relationship in GFI among species. Although we used 129 to 245 individual larvae per species (except for Stichaeus punctatus) (Table 1), all parametric analyses represent the mean within a unit of body length $(1 \mathrm{~mm}$ length intervals converted to dry weight) for each species to provide conservative esti- 
mates. Each observation was weighted by the inverse of the standard deviation for each unit of measurement. We use $F$-values calculated when each variable is the last added to the model (Type III).

Consumption rates were estimated by calculating the diurnal change in GFI per hour for each species of larval fish, after taking into account evacuation rates. We chose to use the cumulative probability distribution (CDF) of GFI instead of some measure of central tendency (e.g. mean or median) to provide a fuller description of the changes in stomach contents taking place over a diurnal cycle. This approach is based on Hall et al.'s (1995) model, with 2 important differences. Our estimates of the CDF are based on the use of local non-parametric density estimators (Davison \& Hinkley 1997) which make no assumptions about the underlying form of the density distribution or the parameters which describe it, and which are generally less sensitive to outliers than methods which estimate central tendency. (The approach is described in greater detail by Evans \& Rice 1988 and Pepin et al. 1999.) Consequently, we could not use Hall et al.'s (1995) iterative minimization scheme to estimate the parameters that best describe the distribution of meal sizes required to achieve the changes in the distribution of GFI from one period to the next. We did not wish to make any assumptions about the underlying distribution of observations or of the processes that lead to them. Consequently, use of minimization schemes would have been unlikely to have provided a unique solution. As a result, the difference between distributions of GFI over time represents an integrated measure of the feeding rates required to achieve such changes. This approach effectively underestimates the extremes of the distributions of consumption rates.

In order to describe diurnal patterns in stomach contents using non-parametric local density estimators, we face the statistical question: what is the probability distribution of a random variable $y(G F I)$, and how does it depend on some other variable $x$ (time of day)? The cumulative probability distribution $F(y)$ is the probability that a value chosen at random will be less than $y$. To compute the local influence of $x$ on $y$, we applied the generalized concept of locally-weighted estimates of the CDF using kernel smoothing. We made a local assumption: observations near to the target $x$ are more relevant for estimating the distribution at $x$. More formally, following Davison \& Hinkley (1997), the CDF is:

$$
\hat{F}(y)=\frac{\sum H\left(y-y_{i}\right) w\left\{\left(x-x_{i}\right) / b\right\}}{\sum w\left\{\left(x-x_{i}\right) / b\right\}}
$$

where $H(z)$ is the Heaviside function ( 0 for $z<0$ and 1 for $z>0$ ). The ogive is a step function whose steps are of different heights, decreasing as the corresponding $x_{i}$ is further from $x$. The step sizes depend only on the distances between $x$ and the different $x_{i}$, where the steps occur depends only on $y_{i}$. We used the weighting function $w(d)=\mathrm{e}^{-d}$, where $d=\left|x_{i}-x\right| / b$, and $b$ is a bandwidth parameter which describes how far local extends. In this study, the weighting reflected the cyclic nature of diurnal feeding patterns (e.g. estimates at 23:00 h were influenced equally by observations at 20:00 and 02:00 h). The value of $b$ can be chosen by cross-validation but in this study we set $b=3$ (h) to reflect the influence which food previously ingested might have had on stomach fullness because catches of larvae were uneven during the day; $3 \mathrm{~h}$ represent the maximum clearance rate measured in previous studies as well as the e-folding scale (time required for stomach contents to decrease by $\sim 63 \%$ ) for the longest observation (8 h) (Sumida \& Moser 1980, Boehlert \& Yoklavich 1983, Tilseth \& Ellertsen 1984, Young \& Davis 1990, Canino \& Bailey 1995, Johnston \& Mathias 1996, Lough \& Mountain 1996).

To determine if the diurnal change in median gut fullness for each species occurred by chance alone, we use a randomization test. (We computed the median at a representative set of times for the original data, and also for 500 synthetic data sets in which the assignment of pairs of variables [time, GFI] is randomized. The median at a given time is significantly greater/less than average if it is greater/less than $97.5 \%$ of the medians for randomized data sets at that size.) Significance was evaluated only at times where there were observations for a species. Randomization was also used to determine if variability in gut fullness fluctuated diurnally. As a measure of variability we chose the difference in GFI between the 10th and 90th percentiles which, for brevity, we shall refer to as the scatter throughout this paper. Large numbers of observations are required to accurately describe the observations in the extreme tails of the distribution beyond the 10th and 90th percentiles.

Weight-specific ingestion rates were calculated based on the difference between the distribution of log-transformed GFI for each hour of a diurnal cycle after accounting for gut evacuation. Gut evacuation for all species of fish larvae was assumed to follow an exponential decay that is $95 \%$ complete in $6 \mathrm{~h}$, which is at the mid-point of values estimated from laboratory studies (Sumida \& Moser 1980, Boehlert \& Yoklavich 1983, Tilseth \& Ellertsen 1984, Young \& Davis 1990, Canino \& Bailey 1995, Johnston \& Mathias 1996, Lough \& Mountain 1996). For each $1 \mathrm{~h}$ time period, $t$ to $t+1$, we subtracted the amount of material which passed from the gut for each point of the cumulative probability distribution $(F(y))$ as

$$
F(C)=F\left(G F I_{t+1}\right)-\left[F\left(G F I_{t}\right)-k F\left(G F I_{t}\right)\right]
$$




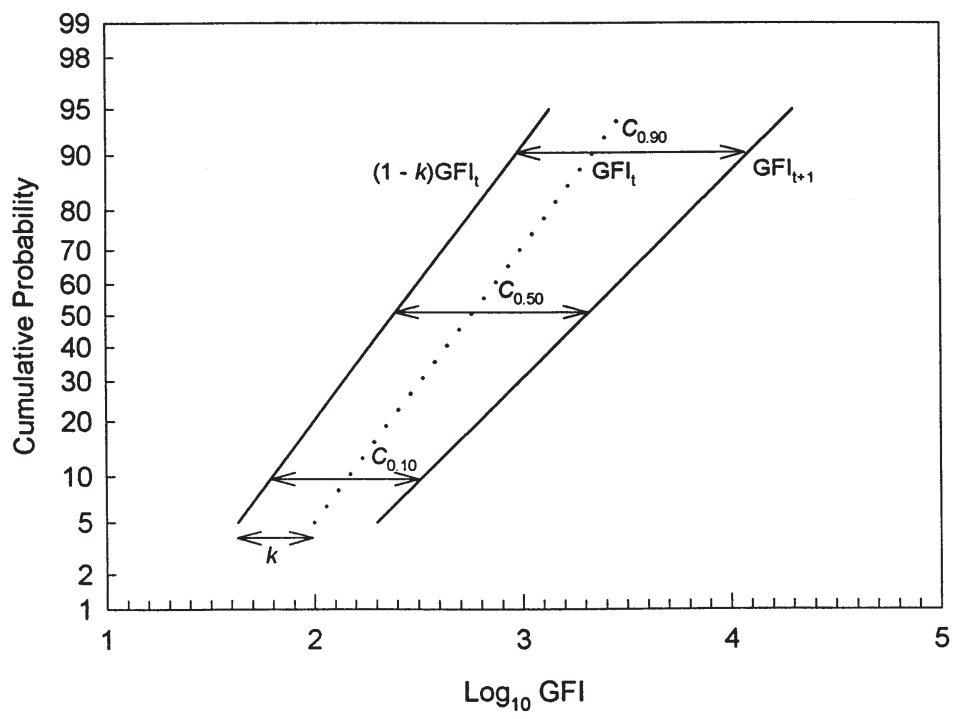

Fig. 1. Schematic diagram showing approach taken to estimate consumption rates of each species of larval fish based on distribution of gut fullness index $(G F I)$. Evacuated portion of gut contents $(k)$ is subtracted from cumulative probability distribution (CDF) of GFI at time $t$. Consumption $(C)$ required at each point of CDF is then estimated as difference between observations at times $t+1$ and $t$ (after correcting for evacuation)

where $k$ is the gut evacuation rate set at $0.5 \mathrm{~h}^{-1}$, and $C$ is the instantaneous weight-specific ingestion rate $\left(\mathrm{h}^{-1}\right)$ required to change the distribution (Fig. 1).

Because we had to make assumptions about evacuation rates, we performed a sensitivity analysis of our calculations using the extremes observed in other studies ( 3 and $8 \mathrm{~h}$ ). The impact of each species of larval fish on the zooplankton community was estimated by separating the total consumption according to the empirical distribution of prey widths observed in the stomachs of each length category of each species of larvae (reported in Pepin \& Penney 1997). The total amount consumed by the ichthyoplankton community was calculated by summing over all species and length intervals.

\section{RESULTS}

\section{Stomach contents}

The total weight of prey ingested in relation to larval weight followed an allometric relationship for all species (Fig. 2, Table 2). There is considerable variation in the height (i.e. intercept) of the relationship among the various species studied, with the clupeoids (Clupea harengus, Mallotus villosus) showing the smallest average GFIs. Other species (e.g. flatfishes) showed little similarity among closely related taxa. Although there was an indication of significant differences in the allometric slopes among the various species, the overall contribution in terms of explained variance was very small $(<0.2 \%$ of the variance), suggesting that all species follow a similar isometric relationship between mean weight of prey in the stomachs and body weight.

\section{Feeding periodicity}

The distribution of stomach contents showed a skewed distribution, approaching a lognormal, at all times and for all species (Fig. 3). GFI varied diurnally, with gut fullness showing a marked increase late in the afternoon or in the early evening in 10 of 11 species and reaching a peak around midnight. Only cunners (Tautogolabrus adspersus) exhibited a different pattern, whereby stomach fullness increased after dawn and began to decrease in the late afternoon. Randomization tests showed that the observed pattern in gut fullness exhibited significant diurnal variation in all species. Species with the highest GFI

Table 2. Allometric models and analysis of total stomach contents for individual species $\left(\log _{10}\right.$ [wt of stomach contents] $=a+b \log _{10}$ [larval wt], where $a$ and $b$ are intercept and slope, respectively, and all weights are in mg dry wt) (A), and results of analysis of covariance contrasting those relationships (B). F-values reported are based on Type III sums of squares

\begin{tabular}{|c|c|c|c|c|c|}
\hline $\begin{array}{l}\text { (A) } \\
\text { Species }\end{array}$ & & Intercept (SE) & Slope (SE) & $\mathrm{R}^{2}$ & $\mathrm{p}$ \\
\hline \multicolumn{2}{|l|}{ Clupea harengus } & $1.29(0.18)$ & $0.66(0.17)$ & 0.71 & 0.009 \\
\hline \multicolumn{2}{|l|}{ Gadus morhua } & $2.07(0.09)$ & $0.86(0.09)$ & 0.9 & 0.0001 \\
\hline \multicolumn{2}{|c|}{ Glyptocephalus cynoglossus } & $2.07(0.12)$ & $1.08(0.11)$ & 0.92 & 0.0001 \\
\hline \multicolumn{2}{|c|}{ Hippoglossoides platessoides } & $S \quad 1.98(0.064)$ & $1.18(0.049)$ & 0.98 & 0.0001 \\
\hline \multicolumn{2}{|l|}{ Liparis sp. } & $2.18(0.065)$ & $0.87(0.073)$ & 0.95 & 0.0001 \\
\hline \multicolumn{2}{|l|}{ Mallotus villosus } & $1.37(0.081)$ & $0.84(0.063)$ & 0.96 & 0.0001 \\
\hline \multicolumn{2}{|c|}{ Pleuronectes ferrugineus } & $1.99(0.13)$ & $0.93(0.087)$ & 0.93 & 0.0001 \\
\hline \multicolumn{2}{|c|}{ Pleuronectes americanus } & $2.66(0.37)$ & $1.26(0.18)$ & 0.93 & 0.002 \\
\hline \multicolumn{2}{|c|}{ Stichaeus punctatus } & $2.06(0.085)$ & $0.91(0.11)$ & 0.9 & 0.0002 \\
\hline \multicolumn{2}{|c|}{ Tautogolabrus adspersus } & $1.79(0.035)$ & $0.77(0.025)$ & 0.99 & 0.0001 \\
\hline \multicolumn{2}{|c|}{ Ulvaria subbifurcata } & $1.95(0.08)$ & $1.00(0.15)$ & 0.9 & 0.001 \\
\hline \multicolumn{6}{|l|}{ (B) } \\
\hline Source & $\mathrm{df}$ & Type I SS & Гype III SS & $F_{\text {III }}$ & $\mathrm{p}$ \\
\hline Weight & 1 & 3.35 & 0.9 & 574 & 0.0001 \\
\hline Species & 10 & 0.81 & 0.19 & 12.1 & 0.0001 \\
\hline Species $\times$ Weight & 10 & 0.1 & 0.1 & 4.22 & 0.0001 \\
\hline Error & 79 & 0.12 & & & \\
\hline
\end{tabular}




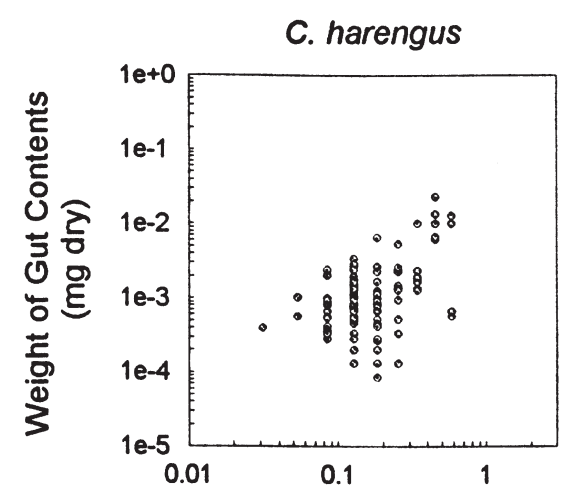

G. cynoglossus

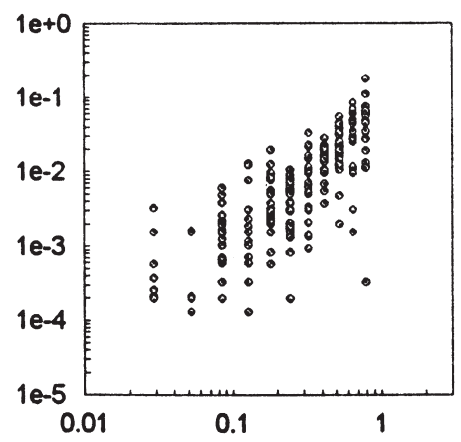

H. platessoides

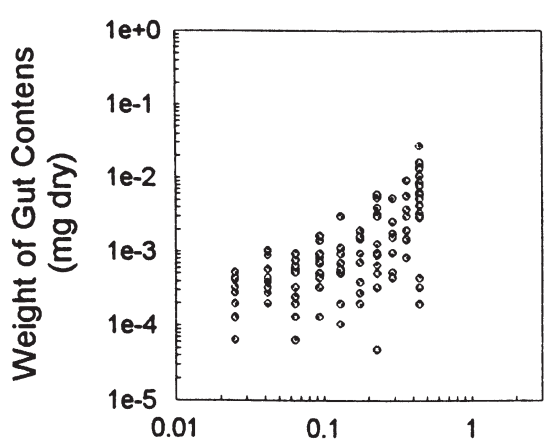

S. punctatus

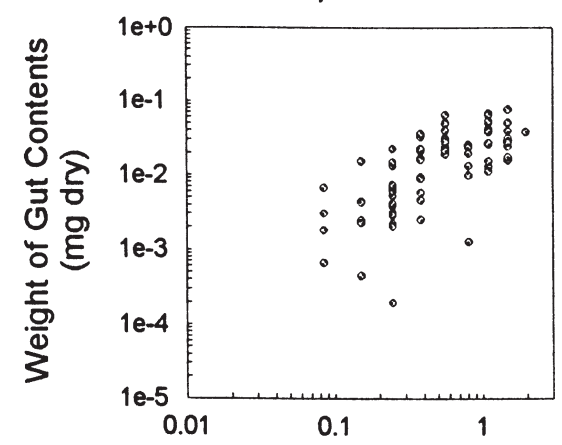

U. subbifurcata

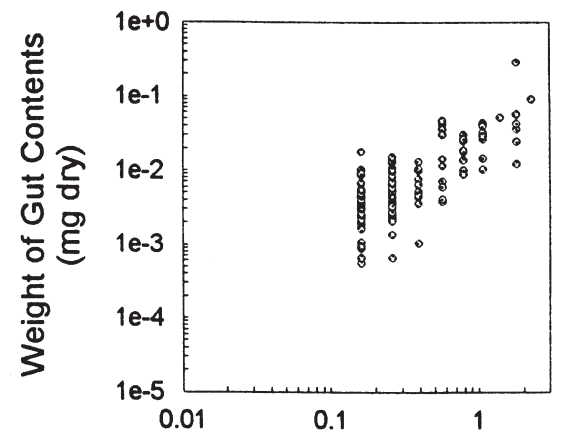

\section{H. platessoides}

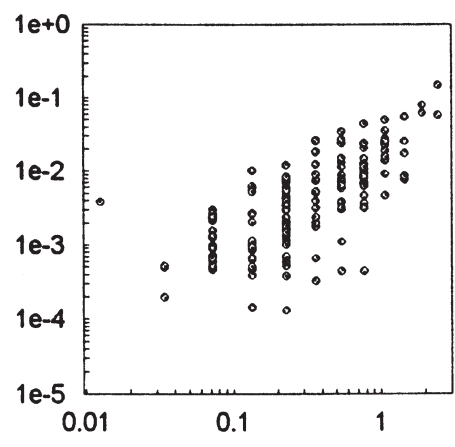

P. ferrugineus

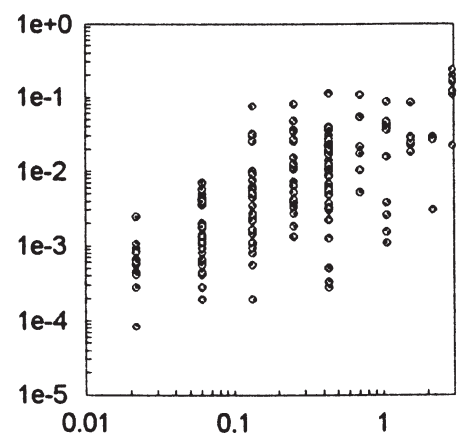

P. americanus

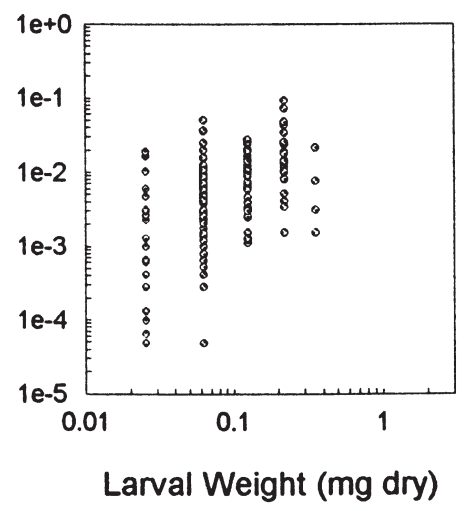

G. morhua

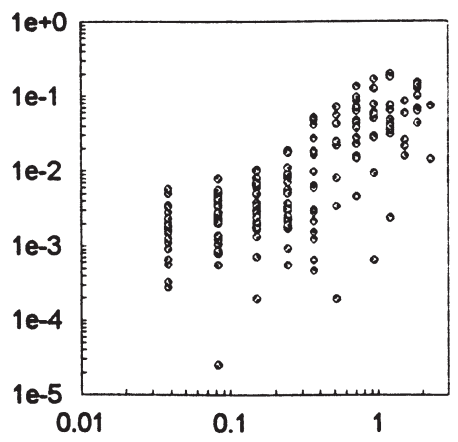

Liparis sp.

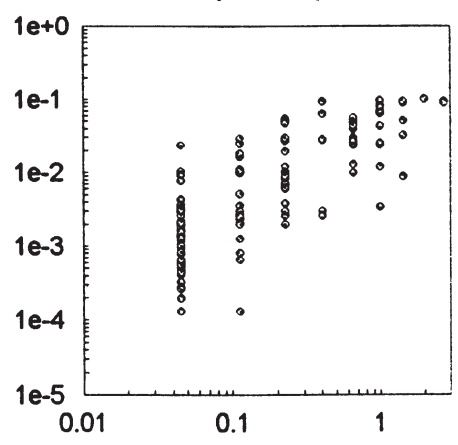

T. adspersus

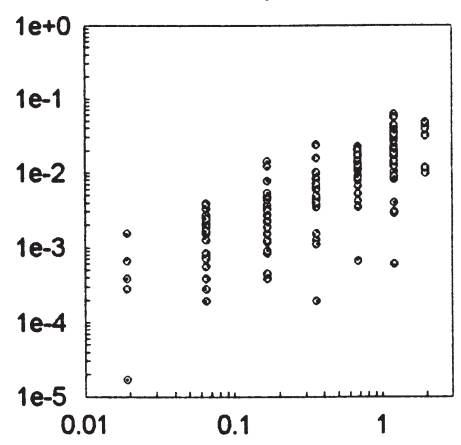

Fig. 2. Allometric relationships for total dry weight of gut contents in relation to larval dry weight. Species full names and details are listed in Table 2 


\section{C. harengus}

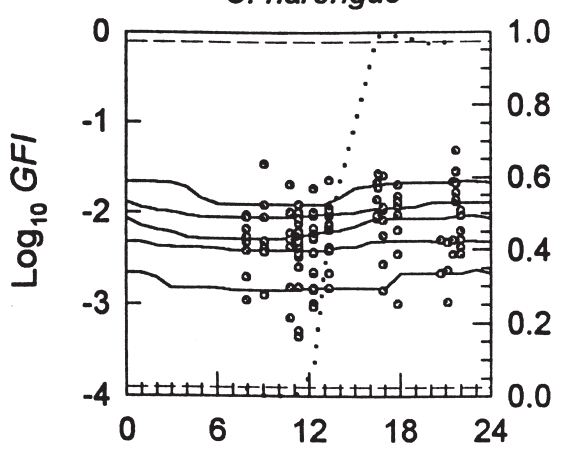

M. villosus

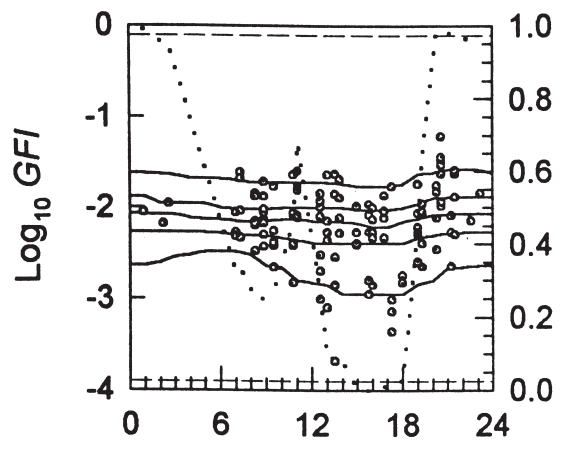

S. punctatus

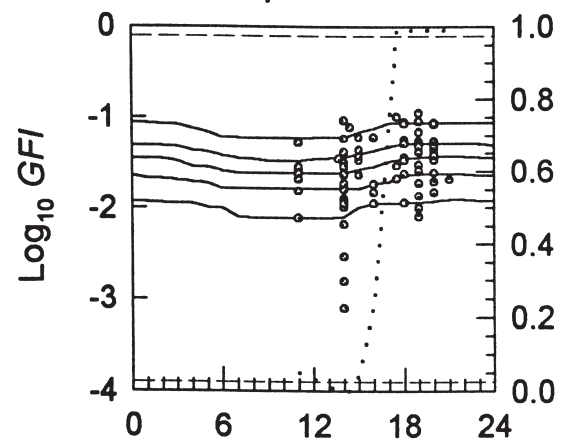

U. subbifurcata

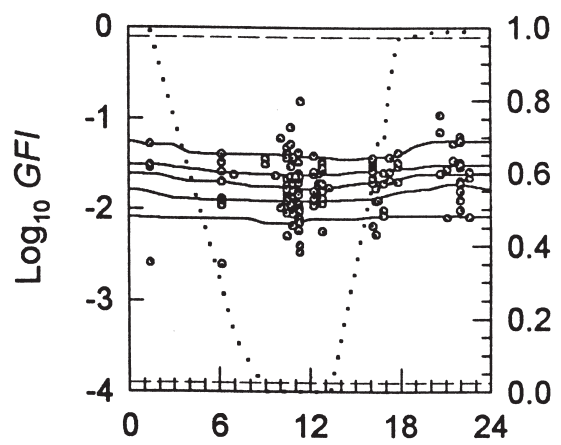

G. cynoglossus

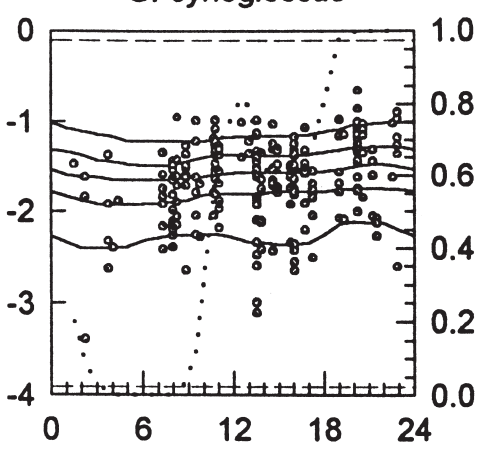

H. platessoides

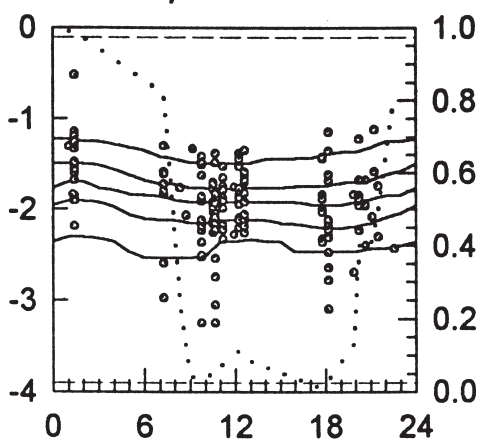

$P$. ferrugineus

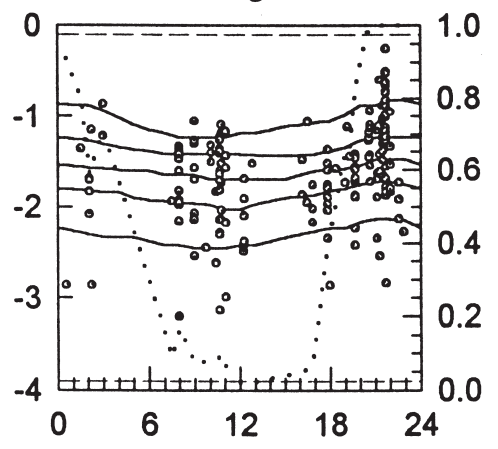

$P$. americanus

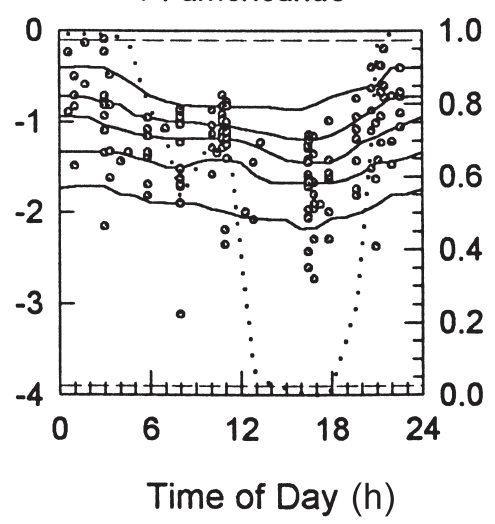

\section{G. morhua}

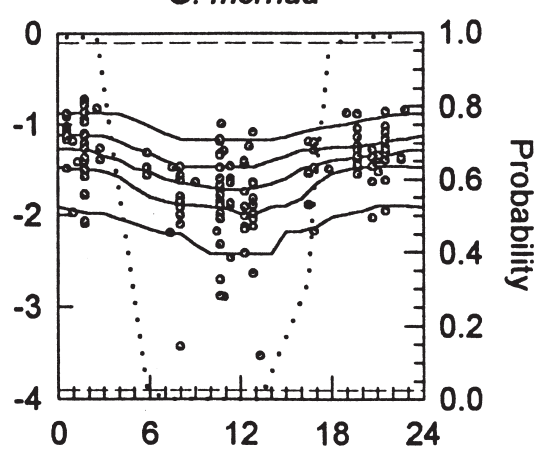

Liparis sp.

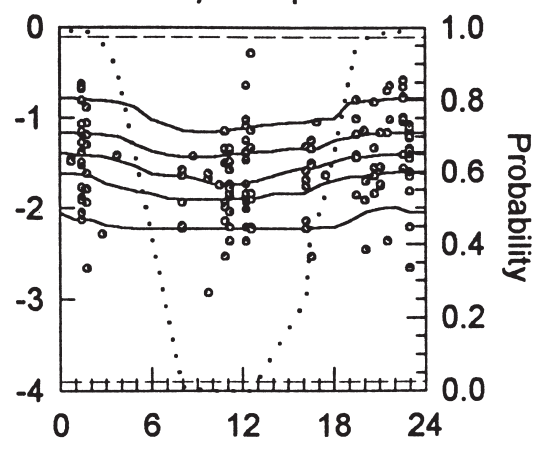

T. adspersus

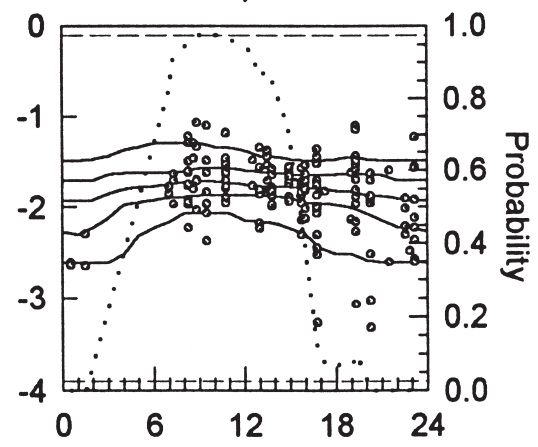

Fig. 3. Diurnal pattern in cumulative probability distribution of GFI ( $\log _{10^{-}}$ transformed) (left axis) for each species of larval fish. Continuous lines: 10th, 30th, 50th, 70th and 90th percentiles of $\mathrm{CDF}_{\text {; }}$ dotted lines: probability (right axis) of measuring estimated median GFI relative to a randomization of data for each species (if median is significantly greater/less than would be expected from randomization of data, then dotted line appears in upper/ lower $2.5 \%$ of randomized data sets generated in simulations); dashed lines: upper and lower $2.5 \%$ marks 
showed the greatest degree of diurnal periodicity in stomach fullness.

Scatter in gut fullness (10th to 90th percentiles) spanned about 1 order of magnitude in species with straight guts whereas it spanned approx. 1.3 orders of magnitude in the majority of species with complex convoluted guts (Fig. 3). In 9 of 11 species, there was no significant variation in the scatter in gut fullness throughout the day. Only in Clupea harengus and in Tautogolabrus adspersus did randomization tests indicate a significant decrease in the scatter in gut fullness between the hours of 09:00 to 14:00 and 08:00 to 15:00, respectively, relative to the remainder of the day.

Estimates of weight-specific ingestion rates indicated that despite decreases in GFI during the day (the opposite was true for Tautogolabrus adspersus) (Fig. 3), feeding by the larval fish population continued throughout the day to some degree (median $\sim 1$ to $2 \%$ of body weight per hour) (Fig. 4), even with the low evacuation rates used in our calculations. Species with straight guts (Clupea harengus, Mallotus villosus) had the lowest ingestion rates, whereas species with well-developed digestive systems had higher ingestion rates. Winter flounder (Pleuronectes americanus) had the highest relative ingestion rate $(\sim 2$ to 3 times that of most other species). Overall changes in the amount of food in the stomachs were greatest, in absolute terms, in the upper percentiles of the distribution but in relative terms, ingestion rates were most variable in the lower percentiles of the distribution of stomach contents. There was generally a 4 - to 6 -fold difference between the lowest and highest hourly individual ingestion rates within a given species at times of peak feeding rates.

The median hourly integrated weight-specific ingestion rate $\left(\int C_{t} \cdot F\left(C_{t}\right)\right)$ of most species varied between 1 and $4 \%$ of body wt $\mathrm{h}^{-1}$ (Fig. 5). Exceptions to this were Clupea harengus and Mallotus villosus, which had feeding rates below $1 \%$ body $\mathrm{wt}^{-1}$, and Pleuronectes americanus, which ingested between 4 and $12 \%$ of its body $\mathrm{wt} \mathrm{h}^{-1}$. When integrated over a complete diurnal cycle, the average larva ingested between 15 and $150 \%$ of its body weight, depending on the species (Fig. 5). Most species ingested 30 to $70 \%$ of their body weight daily, whereas $C$. harengus and $M$. villosus ingested an average of $15 \%$ of their body weight. $P$. americanus ingested approx. 10 times that amount. Because our observations were nearly log-normal within any species and time interval, the overall estimates of total daily consumption are similar to those obtained using the cycle in median gut fullness.

Sensitivity analysis revealed that estimated consumption rates of each species increased by about $50 \%$ if the evacuation time was reduced to $3 \mathrm{~h}\left(k=0.99 \mathrm{~h}^{-1}\right)$, and decreased by $27 \%$ if evacuation times were increased to $8 \mathrm{~h}\left(k=0.37 \mathrm{~h}^{-1}\right)$ (Fig. 6).

\section{Ichthyoplankton community}

Larval fish abundance and overall community structure show a marked seasonal variation (Fig. 7). The number of species, and their overall abundance and biomass increased from May (Day 141) through July/August ( Day 210), after which community structure began to decrease in complexity, but the total number of larvae remained high (Fig. 8). Stichaeus punctatus, Hippoglossoides platessoides and Liparis sp. dominated the larval fish community in May and June (Days 140 to 180), with abundance of $\sim 1$ larva $50 \mathrm{~m}^{-3}$. Atlantic cod (Gadus morhua) was present throughout the study period but generally comprised a minor element of the larval fish community, except in early July when it was the second most abundant species. American plaice (Pleuronectes platessoides) showed a similar pattern, but it disappeared from the plankton in August ( Day 240), as the larvae underwent metamorphosis and settled to the bottom. The community was dominated by the appearance of capelin (Mallotus villosus) in July through September (Day 200 and beyond): at its peak their abundance was at least 10 to 30 times greater than the next most abundant species (Fig. 7). In late summer, cunners (Tautogolabrus adspersus) and witch flounder (Glyptocephalus cynoglossus) appeared as important elements of the ichthyoplankton community. In most species, there was no major increase in cohort biomass after the peak in larval numbers (Fig. 7), in contrast to observations by Houde (1997) in Chesapeake Bay. Often, the overall biomass of a species remained relatively level or decreased slightly after numerical abundance had peaked. Growth and mortality (which includes both biological loss and transport) appear to have been balanced, or with the latter slightly higher.

Total biomass of the ichthyoplankton community followed a pattern similar to that of total abundance (Fig. 8). Lowest biomass levels occurred in late May and early June (Days 150 to 170: $0.005 \mathrm{mg} \mathrm{m}^{-3}$ ), increased gradually from June until August, and then remained relatively high into September $(\sim 0.3$ to $0.5 \mathrm{mg} \mathrm{m}^{-3}$ : Fig. 8). From May through July, the peak biomass moved from large $(\sim 10 \mathrm{~mm})$ to smaller $(\sim 5 \mathrm{~mm})$ larvae. This reflected a change in community from one dominated by Stichaeus punctatus to one with large numbers of capelin (Mallotus villosus) and cunner (Tautogolabrus adspersus) larvae. The subsequent development of the latter species moved biomass into larger size categories by September. In May, most of the biomass was found in $S$. punctatus, whereas in June the biomass distribution was shared between Atlantic cod, American plaice, S. punctatus and Liparis sp. 
C. harengus

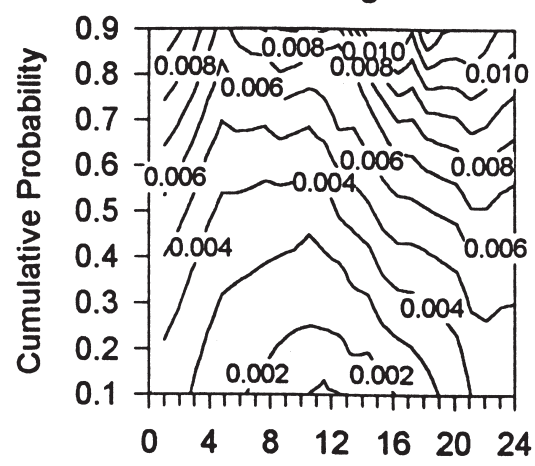

M. villosus

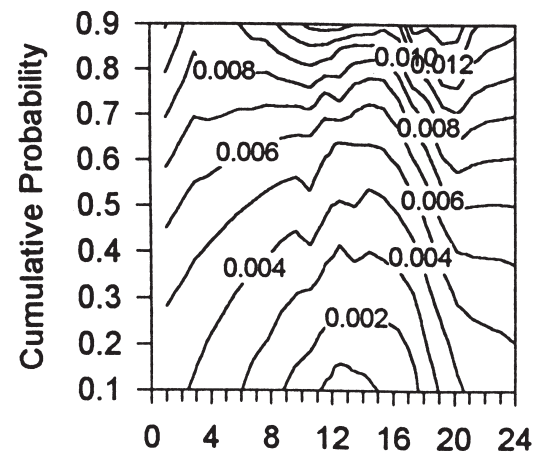

S. punctatus

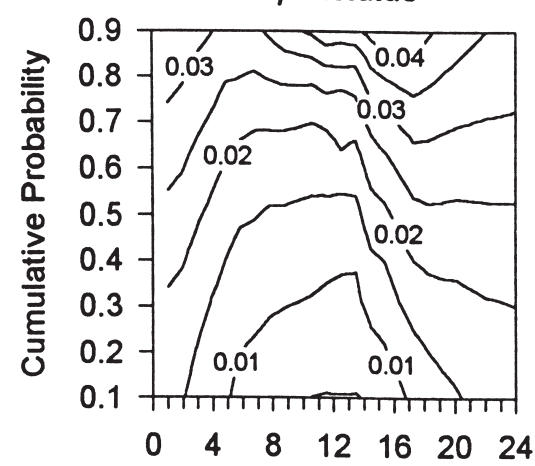

U. subbifurcata

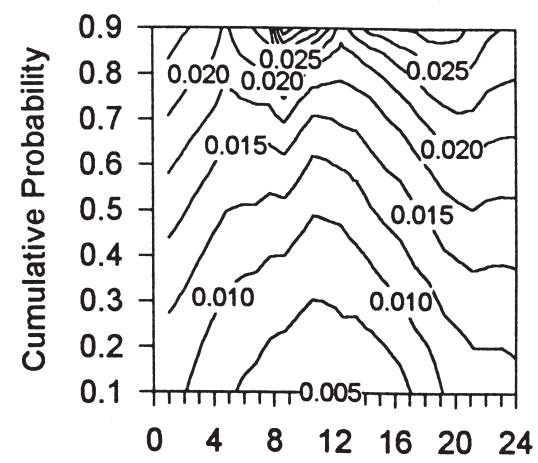

G. cynoglossus

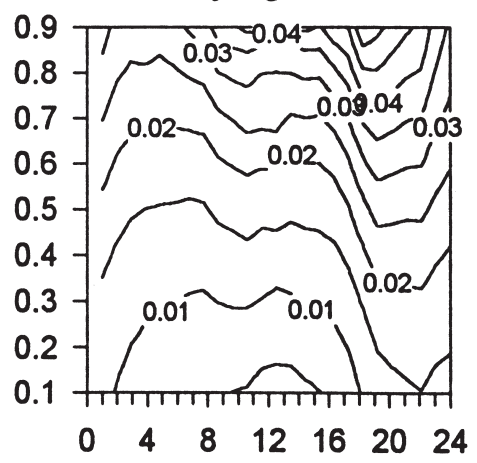

H. platessoides

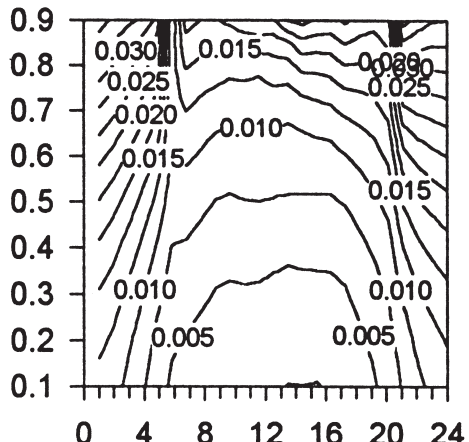

P. ferrugineus

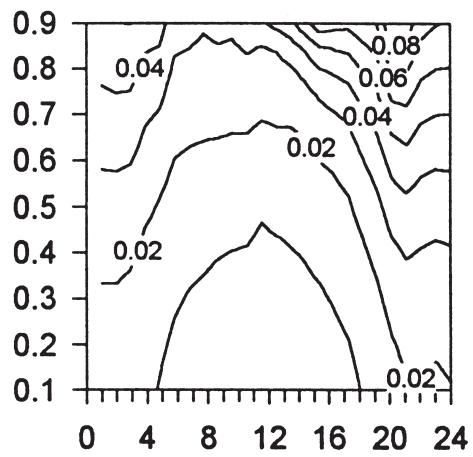

$P$. americanus

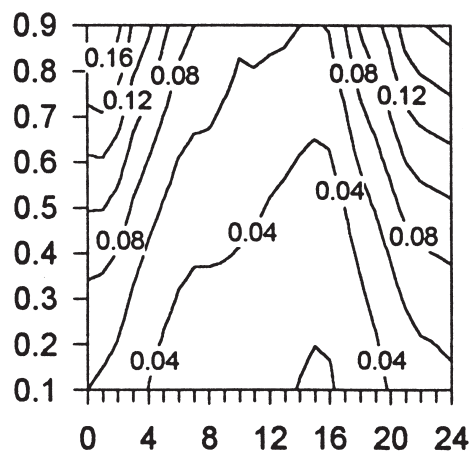

Time of Day (h)
G. morhua

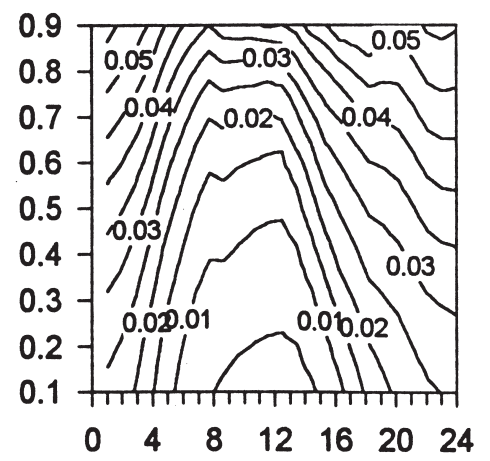

Liparis sp.

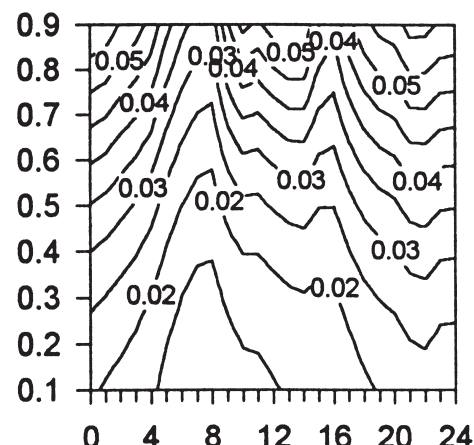

T. adspersus

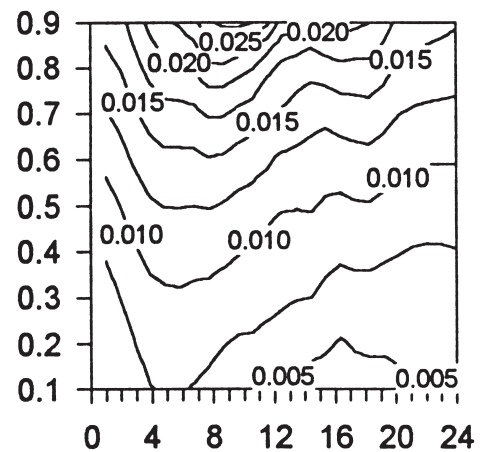

Fig. 4. Contour diagram of the diurnal cycle of cumulative probability distribution in estimated hourly weight-specific ingestion rates for each species. See 'Materials and methods', Eq. (3) and Fig. 1 for details of calculations 


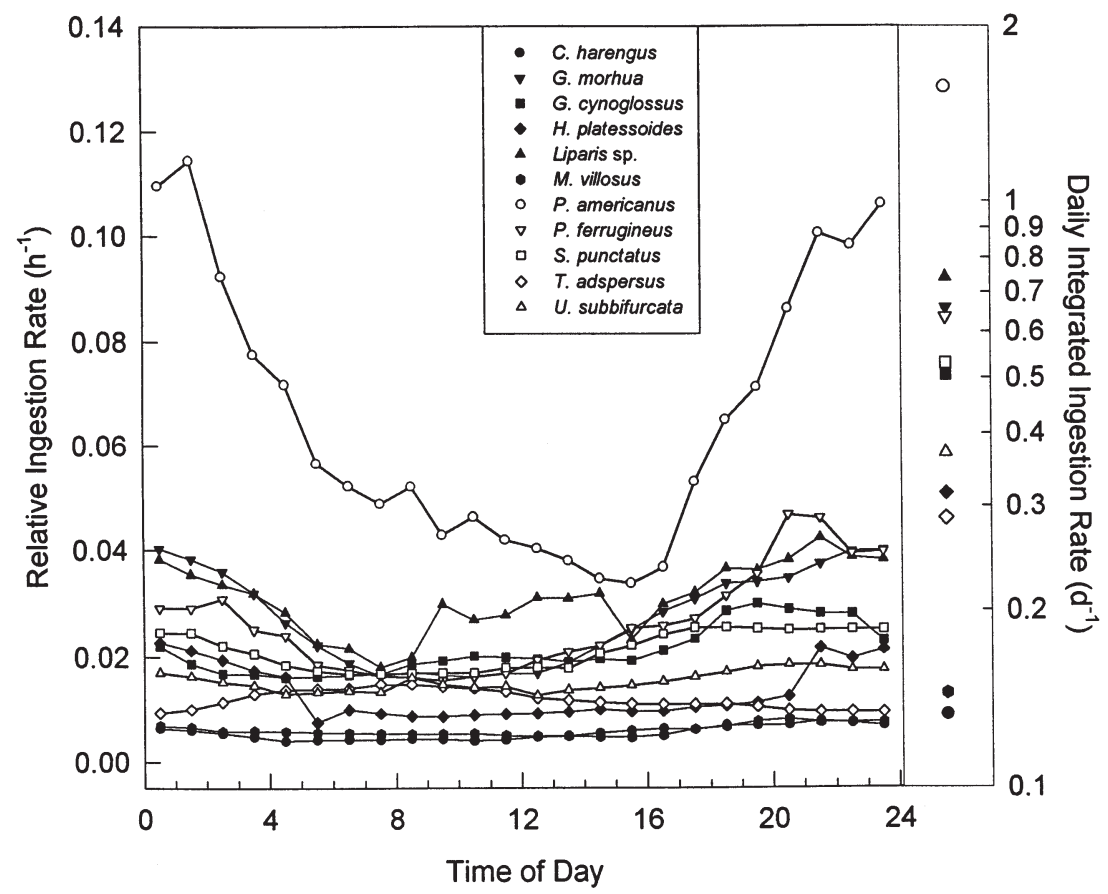

Fig. 5. Median relative hourly weight-specific ingestion rate $\left(\int C_{t} \cdot F\left(C_{t}\right)\right)$ for 11 species of fish larvae; scale is shown on left-hand axis. Points at extreme right of graph show integrated daily median weight-specific ingestion for the 11 species; scale for this is shown on right-hand axis

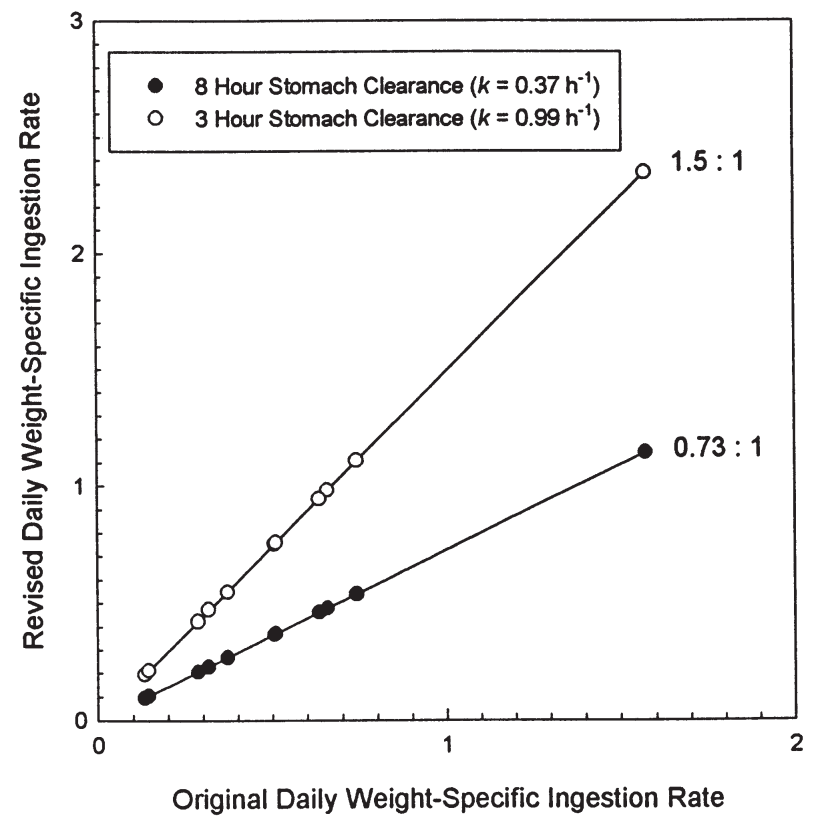

Fig. 6. Results of sensitivity analysis of evacuation rates, showing revised estimated daily consumption rates for 11 species considered in this analysis in relation to those estimated as part of this study. Original weight-specific ingestion rate represents value estimated using evacuation rate of $0.5 \mathrm{~h}^{-1}$. Results are shown for sensitivity analysis using faster $\left(k=0.99 \mathrm{~h}^{-1} ;\right.$ O) and slower $\left(k=0.37 \mathrm{~h}^{-1} ; \bullet\right)$ evacuation rates. Each point represents the estimate for an individual species. Values on right hand side: slope of the relationships

\section{Impact on zooplankton}

There was relatively little change in the size distribution of available prey for fish larvae from May to September, although larger size categories were somewhat less abundant in May (Fig. 9). The overall impact of the ichthyoplankton community on zooplankton abundance was negligible: generally $<0.1 \%$ of the zooplankton, of any size category, was consumed by the entire larval fish community on any given day (Fig. 9). This conclusion is largely unchanged by the value of the evacuation rate used in our calculations (Fig. 6). The seasonal pattern in total prey consumption mimicked the seasonal changes in overall biomass of larval fish. There was a seasonal progression in the size category of microzooplankton most heavily preyed upon by the larval fish community; this moved from $100 \mu \mathrm{m}$ in May to $200 \mu \mathrm{m}$ in September. There was almost no impact on size categories of zooplankton $>350 \mu \mathrm{m}$ in width until July, when larger fish larvae begin to appear in the community.

\section{DISCUSSION}

Despite relatively large numbers of larval fish, and a community composed of a diversity of species, and relatively high, daily, weight-specific ingestion rates (mean $53 \% \mathrm{~d}^{-1}$, range 15 to 150), ichthyoplankton appear to have a very small impact on the abundance of their prey in Conception Bay. Less than $0.1 \%$ of the available prey is consumed on a given day; this is far below the production-to-biomass ratio of 3 to $8 \% \mathrm{~d}^{-1}$ typical for the dominant zooplankton species in this area (Tremblay \& Roff 1983). The potential for densitydependent food limitation of pelagic larval fish appears to be minimal in this coastal ecosystem. This is consistent with suggestions by Cushing (1983) and Jones (1983).

Evacuation rates for larval fish are poorly known; there have been relatively few observations, and their temperature-dependence has not been described. Slight variations in this critical parameter affects estimates of the consumption rate of an individual larva (Fig. 6). Surface mixed-layer temperature in Conception Bay varies over a range of $\sim 10^{\circ} \mathrm{C}$ (5 to $14^{\circ} \mathrm{C}$; 

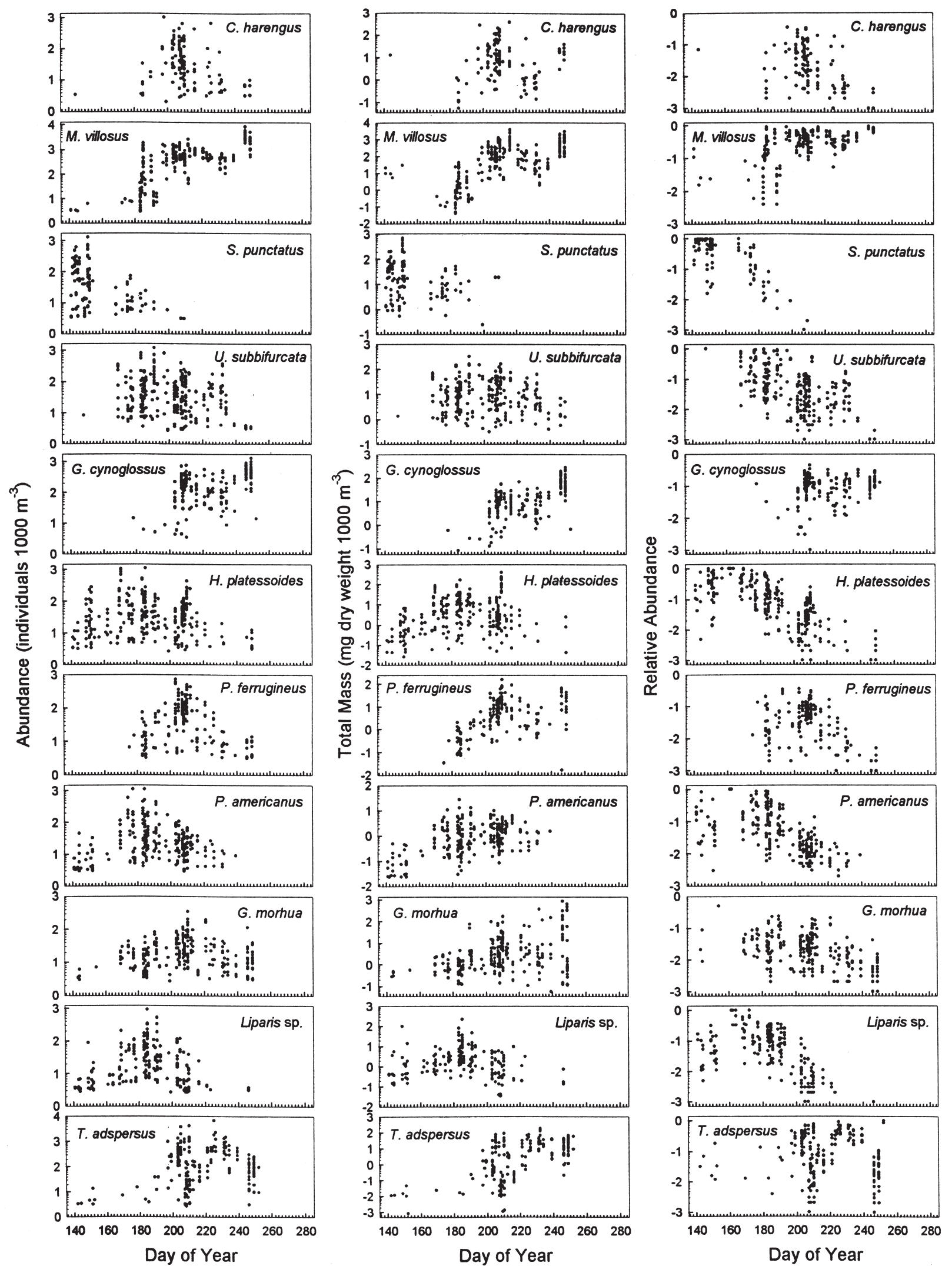

Fig. 7. Seasonal absolute abundance (left column), total biomass (centre column), and relative abundance $\left(N_{i} / \sum_{i} N_{i}\right.$, where $N_{i}=$ the abundance of species $i$ in a sample) (right column) patterns of larval fish in Conception Bay based on individual sample catches 

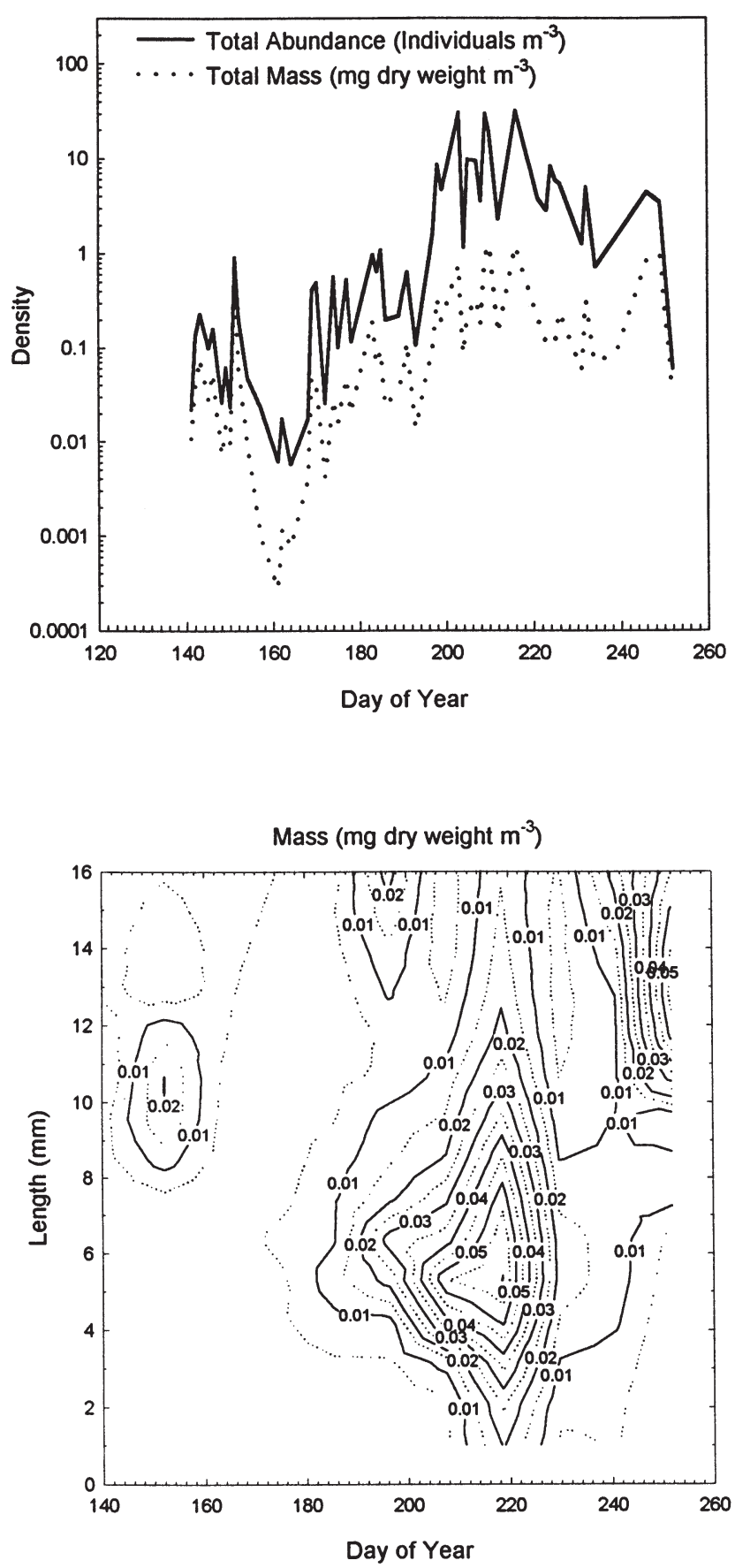

Fig. 8. Seasonal patterns (May to September) of total abundance and biomass of entire larval fish community (top graph) with contoured breakdown of length-dependent biomass distribution (bottom graph)

Laprise \& Pepin 1995, Pepin unpubl. data) during the period when larval fish are present in the system. Since most metabolic processes have a characteristic $Q_{10} \approx 2$, this could have altered both larval evacuation and zooplankton production rates during the course of the study. This might result in a seasonal variation in con-
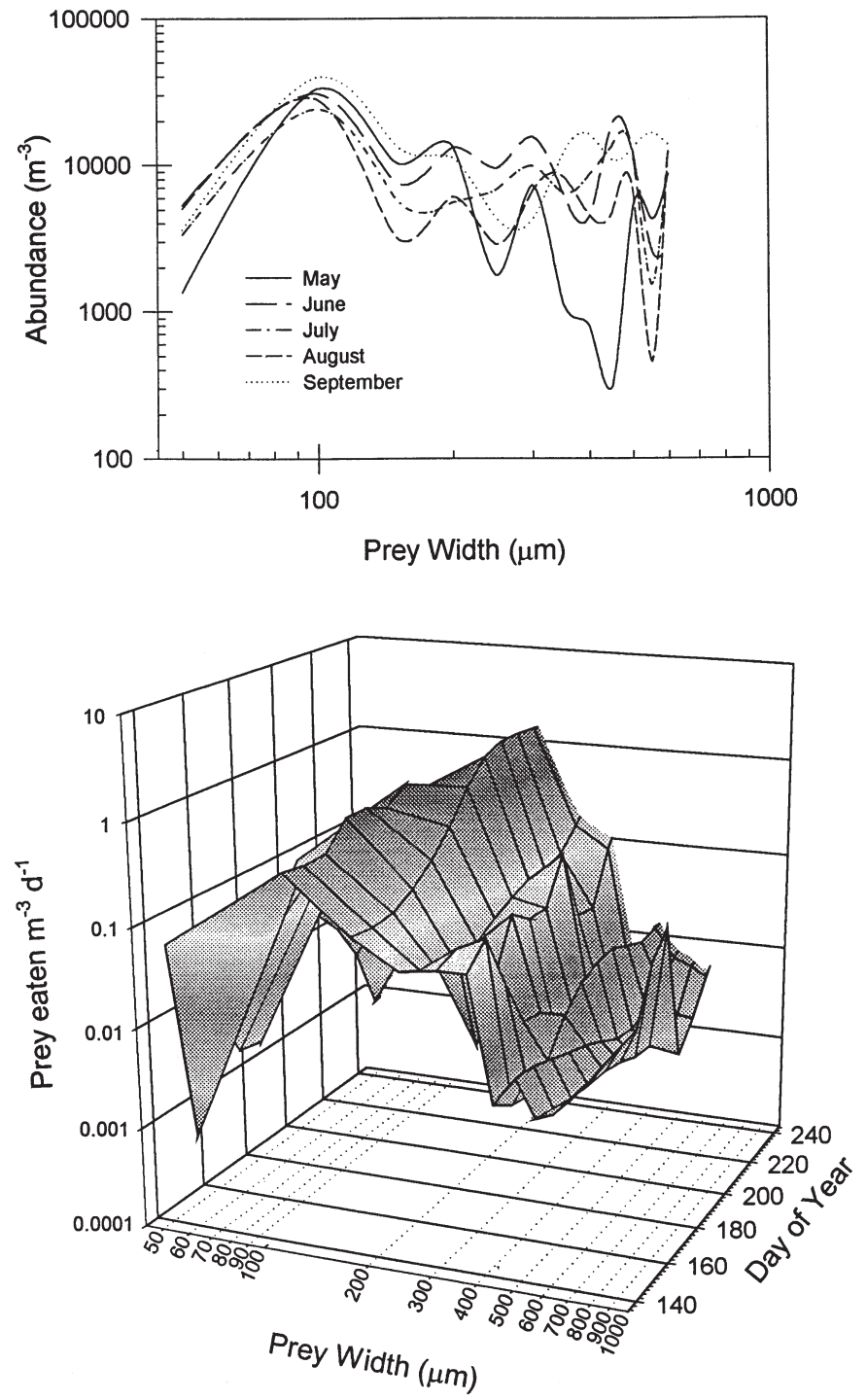

Fig. 9. Monthly pattern of abundance of dominant groups of microzooplankton prey available to fish larvae in relation to prey width (top graph) and cumulated daily impact on prey of larval fish community (bottom graph)

sumption rates relative to that of zooplankton production, but this would likely have a negligible effect on the predicted impact of larvae on zooplankton since we would expect both prey and predator to respond similarly to seasonal fluctuations in physical conditions. Finally, the impact of larval fish on zooplankton calculated in this study is very small, no matter what value we assign to the evacuation rate. As a result, our conclusions are unaffected by our use of an intermediate value for the evacuation rate.

Microzooplankton in Conception Bay is substantially more abundant than has been observed in most of the studies summarized by MacKenzie et al. (1991) in their review. In general, concentrations are 5 to 10 times 
those observed in other shelf and coastal ecosystems. In part, this difference may be an artefact of the choice of sampling gears used to estimate microplankton abundance. Frank (1988) highlighted limitations in previous studies which had not used mesh sizes appropriate for the capture of small prey typically eaten by most fish larvae. This may have led some investigators to suggest that larvae or juveniles could reduce their prey population, which would eventually lead to density-dependent competition because of underestimates of prey concentrations. However, the impact of the larvae on their prey in Conception Bay is so small that even a 10 -fold reduction in prey availability would be unlikely to lead to competition among larval fish. Potential microplankton production would still exceed the impact which fish larvae have on their food resources.

Houde (1997) found that after an initial decrease in the biomass of a cohort caused by mortality exceeding growth, total population biomass began to increase when larvae reached about $10 \mathrm{~mm}$ in body length. In contrast, we found no evidence that the biomass of any species of larval fish in Conception Bay was increasing with increasing length, even though the total biomass of larval fish in the system increased from May to September. There were clear peaks in the time- and length-dependent distribution of larval fish biomass (Fig. 7). However, these reflected shifts in the relative proportion of different species with increasing length. The hatching and release of small larvae tended to dominate certain size categories, but as different species grow at different rates, the relative composition of any larval fish community changes with increasing size. Such shifts in community structure may indicate differential survival rates among cohorts of different species. Alternatively, the lack of an overall biomass increase within individual species as larvae aged may have been due to the dynamic nature of the circulation in Conception Bay (deYoung et al. 1994, Laprise \& Pepin 1995, Pepin et al. 1995). Continuous advection of larvae, particularly capelin, out of Conception Bay may contribute to the lack of increased biomass as well as changes in ichthyoplankton community structure. Transport of larvae in and out of Conception Bay may also have limited the impact that ichthyoplankton might have had on their prey by advecting larvae out of the area and thus limiting growth in biomass of the ichthyoplankton community.

The abundances reported in this study represent local area averages based on large numbers of samples. However, both Frank \& Leggett (1982) and Laprise \& Pepin (1995) found evidence of spatial segregation of ichthyoplankton according to water-mass characteristics. Frank \& Leggett (1982) and Taggart \& Leggett (1987) argued that the pattern of association not only reflected emergence mechanisms for the release of larvae for several fish species with demersal eggs but also adaptations to place larvae in environments with low numbers of predators and high concentrations of available prey. Although the strength of this pattern weakens once larvae begin to disperse into the wider circulation system of Conception Bay (Laprise \& Pepin 1995), there is still considerable patchiness in the distribution of larvae. Larval fish densities in excess of 30 larvae $\mathrm{m}^{-3}$ are not infrequent. Such high densities may lead to local depletions in the prey community. How this may impact the dynamics of fish larvae is unknown. Given the high degree of mixing which takes place throughout the bay (deYoung et al. 1994, Laprise \& Pepin 1995), it seems unlikely that individual larvae would be subject to depleted food conditions over an extensive time period.

Although larval fish feed predominantly on copepod nauplii, they gradually shift their feeding to the larger copepodite stages which provide a greater energy return per unit ingested (Arthur 1976, Last 1978a,b, Economou 1991, Pepin \& Penney 1997). This gradual shift to larger prey, which varies considerably in nature among species (Pepin \& Penney 1997), not only allows more efficient feeding by the larvae but may also serve to reduce the possible impact which larvae have on their food resource. All the species considered in this study exhibit protracted spawning and larval release periods. Shifts in prey preference within a species might serve to limit the degree of competition among cohorts. However, differences in the shift to larger prey among the diverse species in Conception Bay do not show strong evidence of a partitioning of the prey field (Pepin \& Penney 1997). Most size categories of larvae feed on a broad range of prey sizes and species, and there is considerable overlap in the prey field between the smallest and largest larvae (Pepin \& Penney 1997). There is also substantial overlap in the types and sizes of prey eaten by different species that co-occur. Since predation pressure by the larvae on the microzooplankton does not appear substantial, it should not be unexpected that there is little reason to partition resources, either in terms of prey species or sizes eaten by the larvae.

Our use of the complete cumulative distribution of gut fullness provides an indication of the extremes likely to be encountered within a population of fish larvae. Although we were not able to estimate the extremes in the distribution of meal sizes and their frequency, we can infer a conservative estimate of the fraction of the population of a species which does not ingest sufficient food to satisfy their basic metabolic requirements. Based on laboratory studies, Checkley (1984) found that energy intake exceeded metabolic 
demands when the daily weight-specific ingestion rates reached $0.04 \% \mathrm{~d}^{-1}$, based on a comparative analysis of several species. This implies that an average ingestion rate below $0.0016 \%$ body wt $\mathrm{h}^{-1}$ over a full day could lead to an energy deficit which could in turn lead to lower condition (Buckley 1984, Clemmesen 1996). Whether this could lead to eventual starvation or greater vulnerability to predators is unclear. However, when we consider the 11 species of this study, we find that such low feeding rates were seldom observed within the 10th to 90th percentiles considered in this study. At the other extreme, maximum hourly weight specific ingestion rates could reach $\sim 5 \% \mathrm{~h}^{-1}$ in most species with complex guts, and $\sim 1.2 \% \mathrm{~h}^{-1}$ in species with straight guts. Govoni et al. (1986) give no a priori evidence to suggests that such differences are related to gut morphology, as development of the alimentary tract differs little among larval fish until transformation to the juvenile stage. The difference in estimated ingestion rates may reflect differences in the inherent feeding ability among the species considered here. Because there is evidence that patterns in survivorship are related to the persistence in growth rates or condition within individual fish larvae (Meekan \& Fortier 1996, Pepin et al. 1999), the extremes in the distribution of gut fullness may provide an indication of the survival potential among individuals in the population. To validate this hypothesis, there is a need to understand the factors that would allow individual larvae to obtain high rations relative to others in the population, and how this translates into growth of each individual.

Although the impact of the ichthyoplankton community may be negligible, the cumulated impact of all carnivorous plankton on the microzooplankton may not. Medusae and crab zoea are important members of the plankton, reaching average densities between 100 and $1000 \mathrm{~m}^{-3}$ (Frank \& Leggett 1982, Paradis \& Pepin in press). Without further knowledge of the diet of these organisms, it is impossible to assess the potential for competition between fish larvae and the remainder of the zooplankton community. Future studies to assess the impact of grazing on microzooplankton communities need to be broadened to consider all possible predators in the ecosystem.

Acknowledgements. We wish to thank J. Anderson and T. Shears for their assistance in various phases of this project. Nell Stallard, of LGL Limited Environmental Research Associates, performed the analysis of microzooplankton samples and larval fish gut contents. We thank P. Snelgrove and 3 anonymous referees for comments and suggestions concerning this manuscript.

\section{LITERATURE CITED}

Anderson JT, Dalley EL (1997) The nekton of the coastal and shelf waters of Newfoundland. Canadian Stock Assessment Secretariat Research Document 97/124, Ottawa

Arthur DK (1976) Food and feeding of larvae of three fishes occurring in the California Current, Sardinops sagax, Engraulis mordax, and Trachurus symmetricus. Fish Bull US 74:517-530

Boehlert GW, Yoklavich MM (1983) Effects of temperature, ration, and fish size on growth of juvenile black rockfish, Sebastes melanops. Environ Biol Fishes 8:17-28

Buckley LJ (1984) RNA/DNA ratio: an index of larval fish growth in the sea. Mar Biol 80:291-298

Canino MF, Bailey KM (1995) Gut evacuation of walleye pollock larvae in response to feeding conditions. J Fish Biol 46:389-403

Checkley DM (1984) Relation of growth to ingestion for larvae of Atlantic herring Clupea harengus and other fish. Mar Ecol Prog Ser 18:215-224

Clemmesen C (1996) Importance and limits of RNA/DNA ratios as a measure of nutritional condition in fish larvae. In: Watanabe Y, Yamashita Y, Oozeki Y (eds) Survival strategies in early life stages of marine resources. AA Balkema, Rotterdam, p 67-82

Cushing DH (1983) Are fish larvae too dilute to affect the density of their food organisms? J Plankton Res 5:847-854

Davison AC, Hinkley DV (1997) Bootstrap methods and their application. Cambridge University Press, Cambridge (Cambridge Series in statistical and probabilistic mathematics)

deYoung B, Anderson JT, Greatbatch RJ, Fardy P (1994) Advection diffusion modelling of capelin larvae in Conception Bay, Newfoundland. Can J Fish Aquat Sci 51: 1297-1307

Economou AN (1991) Food and feeding ecology of five gadoid larvae in the northern North Sea. ICES J Mar Sci 47: 339-351

Evans GT, Rice JC (1988) Predicting recruitment from stock size without the mediation of a functional relation. J Cons Int Explor Mer 44:111-122

Frank KT (1988) Independent distributions of fish larvae and their prey: natural paradox or sampling artifact. Can J Fish Aquat Sci 45:48-59

Frank KT, Leggett WC (1982) Coastal water mass replacement: its effect on zooplankton dynamics and predatorprey complex associated with larval capelin (Mallotus villosus). Can J Fish Aquat Sci 39:991-1003

Govoni JJ, Boehlert GM, Watanabe Y (1986) The physiology of digestion in fish larvae. Environ Biol Fishes 16:59-77

Hall SJ, Gurney WSC, Dobby H, Basford DJ, Heaney SD, Robertson MR (1995) Inferring feeding patterns from stomach contents data. J Anim Ecol 64:39-62

Houde ED (1997) Patterns and trends in larval-stage growth and mortality of teleost fish. J Fish Biol 51(Suppl A):52-83

Johnston TA, Mathias JA (1996) Gut evacuation and absorption efficiency of walleye larvae. J Fish Biol 49:375-389

Jones R (1983) Species interactions in the North Sea. Can Spec Publ Fish Aquat Sci 59:48-63

Laprise R, Pepin P (1995) Factors influencing the spatio-temporal occurrence of fish eggs and larvae in a northern physically-dynamic coastal environment. Mar Ecol Prog Ser 122:73-92

Last JM (1978a) The food of four species of pleuronecteform larvae in the eastern English Channel and southern North Sea. Mar Biol 45:359-368

Last JM (1978b) The food of three species of gadoid larvae in 
the eastern English Channel and southern North Sea. Mar Biol 48:377-386

Lough RG, Mountain DG (1996) Effect of small-scale turbulence on feeding rates of larval cod and haddock in stratified water on Georges Bank. Deep-Sea Res (II) 43:1745-1772

MacKenzie BR, Leggett WC, Peters RH (1991) Estimating larval fish ingestion rates: can laboratory derived values be reliably extrapolated to the wild? Mar Ecol Prog Ser 67: 209-225

Meekan MG, Fortier L (1996) Selection for fast growth during the larval life of Atlantic cod Gadus morhua on the Scotian Shelf. Mar Ecol Prog Ser 137:25-37

Paradis AR, Pepin P (in press) Modelling changes in the frequency distributions of fish larvae using field estimates of predator abundance and size distributions. Fish Oceanogr

Pearre S (1980) The copepod length-weight relation and its utility in food chain research. Can J Zool 58:1884-1891

Pepin P (1995) An analysis of the length-weight relationship of fish larvae: limitations of the general allometric model. Fish Bull US 93:419-426

Pepin P, Penney RW (1997) Patterns of prey size and taxonomic composition in larval fish: are there general sizedependent models? J Fish Biol 51(Suppl A):84-100

Pepin P, Helbig JA, Laprise R, Colbourne E, Shears TH (1995) Variations in the contribution of transport to changes in planktonic animal abundance: a study of the flux of fish larvae in Conception Bay, Newfoundland. Can J Fish Aquat Sci 52:1475-1486

Editorial responsibility: Kenneth Sherman (Contributing Editor), Narragansett, Rhode Island, USA
Pepin, P, Evans GT, Shears TH (1999) Patterns of RNA/DNA ratios in larval fish and their relationship to survival in the field. ICES J Mar Sci 56:697-706

Sherman K, Smith W, Morse W, Berman M, Green J, Ejsymont L (1984) Spawning strategies of fishes in relation to circulation, phytoplankton production, and pulses in zooplankton off the northeastern United States. Mar Ecol Prog Ser 18:1-19

Smith PE, Lasker R (1978) Position of larval fish in an ecosystem. Rapp PV Réun Cons Int Explor Mer 173:77-84

Sumida BY, Moser HG (1980) Food and feeding of Pacific hake larvae, Merluccius productus, off Southern California and Northern Baja California. Rep Calif Coop Ocean Fish Invest 21:161-166

Taggart CT, Leggett WC (1987) Short-term mortality in postemergent larval capelin Mallotus villosus. II. Importance of food and predator density, and density-dependence. Mar Ecol Prog Ser 41:219-229

Tilseth S, Ellertsen B (1984) Food consumption rate and gut evacuation processes of fish feeding cod larvae (Gadus morhua L.). Flødevigen Rapp 1:167-182

Tremblay MJ, Roff JC (1983) Production estimates for Scotian Shelf copepods based on mass specific P/B ratios. Can J Fish Aquat Sci 40:749-753

Young JW, Davis TLO (1990) Feeding ecology of larvae of southern bluefin, albacore and skipjack tunas (Pisces Scombridae) in the eastern Indian Ocean. Mar Ecol Prog Ser 61:17-29

Submitted: September 29, 1999; Accepted: May 1, 2000

Proofs received from author(s): September 7, 2000 